\title{
Adenoma of the Nipple, Mimicking Paget's Disease of the Breast: Report of a Case
}

\author{
Ahmed Abbas*, Ali Al-Zaher, Ali El Arini, Ikram Chaudhry \\ Department of Surgery, King Fahad Specialist Hospital, Dammam, KSA \\ Email: ${ }^{*}$ ahmednci@gmail.com
}

Received 23 April 2014; revised 20 May 2014; accepted 17 June 2014

Copyright (C) 2014 by authors and Scientific Research Publishing Inc.

This work is licensed under the Creative Commons Attribution International License (CC BY).

http://creativecommons.org/licenses/by/4.0/

(c) (i) Open Access

\begin{abstract}
Nipple adenoma is a rare benign condition that simulates malignancy. A 37-year-old woman presented with unilateral bloody nipple discharge for 1-year duration followed by severe nipple erosion. As biopsy revealed nipple adenoma and therefore, complete local excision was done. The final histopathology showed florid papillomatosis which was adequately excised. Nipple adenoma although rare entity this should be included in the differential diagnosis of any nipple erosion such as carcinoma and Paget's disease of the breast specially when associated with bloody discharge in premenopausal women.
\end{abstract}

\section{Keywords}

\section{Nipple Adenoma, Benign Breast Lesion, Florid Papillomatosis of the Nipple}

\section{Introduction}

Nipple adenoma is a rare benign neoplasm which originates from the nipple of the breast. In 1955 Jones described this first time as florid papillomatosis. Also this condition is known as erosive adenomatosis or superficial papillary adenomatosis. Although this is a benign tumor clinically it is very difficult to differentiate between malignant conditions like carcinoma and Paget's disease of the breast [1]. Patient usually presents with subareolar nodule, pain, nipple discharge, erythema and ulceration

Proper pre-operative diagnosis is essential because any misinterpretation of histopathological report can lead to undue mastectomy as reported by Carter et al. [2].

\section{Case Presentation}

A 36-year-old woman presented with a history of a left sided bloody nipple discharge for one year duration.

"Corresponding author.

How to cite this paper: Abbas, A., Al-Zaher, A., El Arini, A. and Chaudhry, I. (2014) Adenoma of the Nipple, Mimicking Paget's Disease of the Breast: Report of a Case. Advances in Breast Cancer Research, 3, 96-99. 
Subsequently she developed severe nipple ulceration. The patient was seen by a dermatologist and was given systemic antibiotics and local corticosteroids with no response. On physical examination, the left nipple was completely eroded with extensive skin ulceration. Otherwise, both breasts and axillae were clinically free with no palpable lymphadenopathy.

Clinical differential diagnoses included: Paget's disease of the nipple and skin malignancy. However, nipple adenoma was not clinically suspected. Bilateral breast ultrasound and mammogram did not show any abnormality. Small incisional biopsy showed nipple adenoma. A complete excision of the eroded left nipple and part of the surrounded areola was achieved in addition to part of the retro-areolar breast tissue (Figure 1). Microscopically, the nipple showed lesion featuring complex ducts composed of bland oval cells with variable degree of hyperplasia which were focally continuous with squamous epithelium of the skin. The epithelial cells did not display any significant pleomorphism, mitotic activity or necrosis. Focal nipple ulceration is also noted (Figure 2 and Figure 3), without evidence of malignancy. The picture was consistent with nipple adenoma. Nipple reconstruction was planned at a later stage.

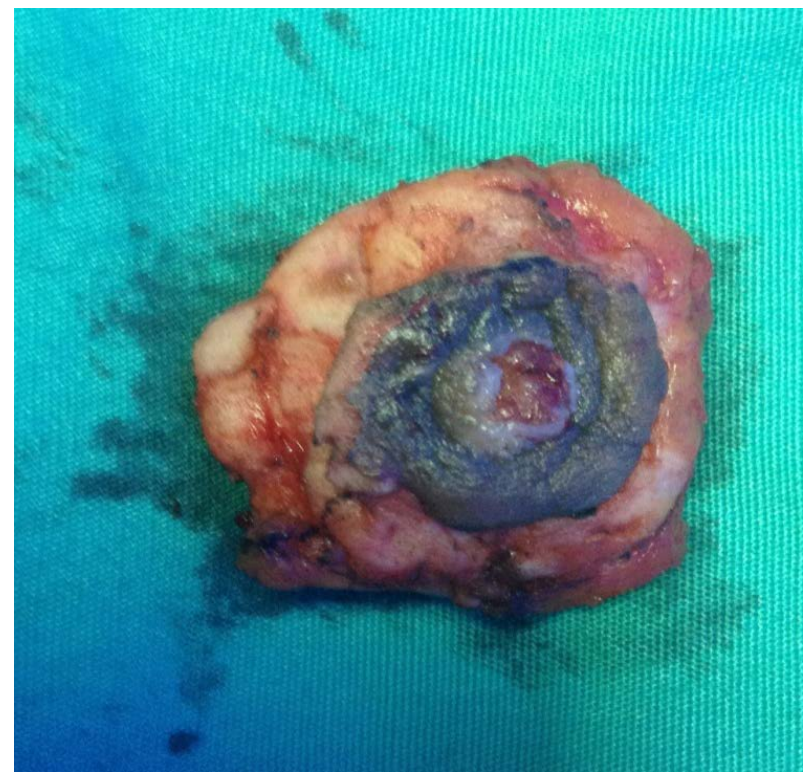

Figure 1. gross picture of the resected specimen including the eroded nipple, part of the areola and underlying breast tissue.

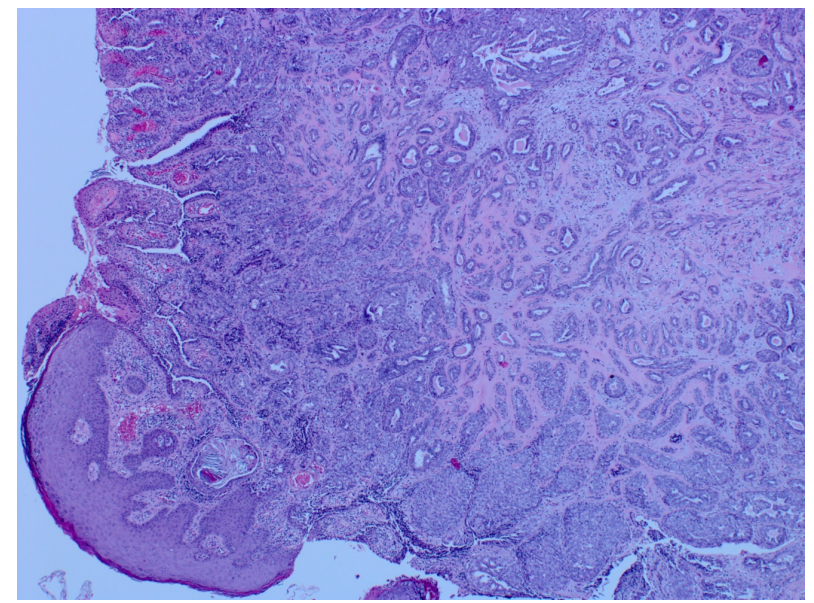

Figure 2. Complex ductal architecture underlying the surface epithelium with focal ulceration. (4× Low-power photomicrograph). 


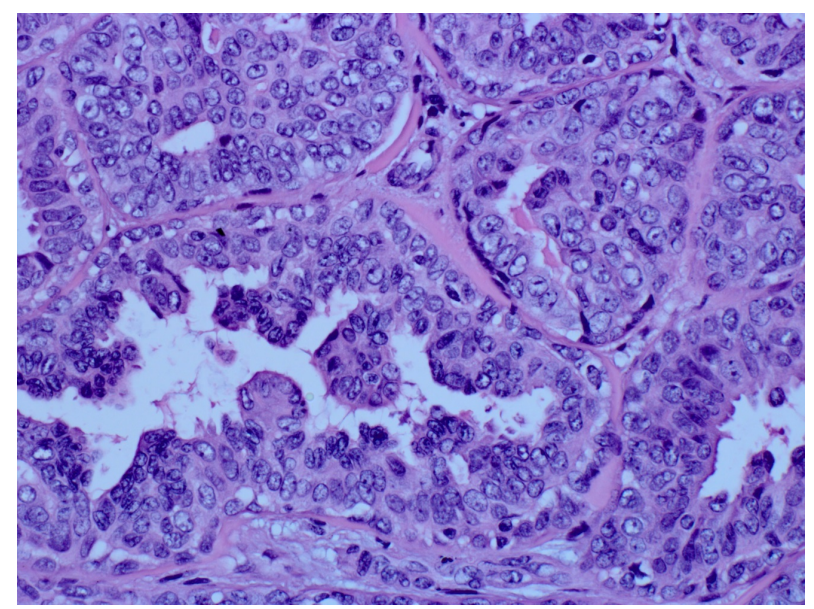

Figure 3. Ducts comprised of bland-looking epithelial cells with variable hyperplasia. (20× High-Power photomicrograph).

\section{Discussion}

Nipple adenoma, also known as florid papillomatosis, erosive adenomatosis or superficial papillary adenomatosis is a benign condition simulating malignancy such as breast carcinoma and/or Paget's disease clinically [1]. Women in their 4th and 5th decades commonly affected and usually they presents with unilateral, serous or bloody nipple discharge in the presence of crusting. The main differential diagnosis is Paget's disease of the nipple based on similar clinical features like soreness, ulceration and swelling of the nipple, sometimes with discharge [3] [4]. However, Paget's disease is more common in older women and Paget's cells can be detected by aspiration biopsy cytology. Whereas adenoma of the nipple tends to occur in premenopausal women.

The pathological characteristics of adenoma of the nipple are the maintenance of a double layer composed of epithelial and myoepithelial cells, no accompanying epithelial necrosis, and a definite direction of the duct cell arrangement in a pattern of pseudo invasion. It can be difficult to distinguish adenoma of the nipple from ductal carcinoma when the adenoma shows a marked proliferation of epithelial cells accompanied by pseudo invasion [5]. The coexistence of carcinoma and nipple adenoma has been noticed before by many investigators, and the reported incidence of this phenomenon varies in different studies. Fisher et al., found that, in a group of 967 patients with carcinoma, $1.2 \%$ had associated nipple adenoma [6].

Nipple adenomas are papillary or solid adenomas developing within the nipple where proliferation of papillary epithelium is remarkable [2] [7]. The histological patterns of nipple adenoma are described by Rosen as adenosis, papillomatosis, mixed proliferative and sclerosing papillomatosis [8].

There is no evidence of metastasis in this disease but local recurrences can occur when the neoplasm is incompletely excised. Hence, nipple reconstruction is usually planned after completeness of excision is confirmed histologically.

Bloody or serous nipple discharge is the most common presenting complaint in $65 \%-70 \%$ of the patients, followed by enlargement and induration of the nipple associated with ulceration, which have been reported in medical literature [9]-[11]. However, histopathological evidence is medatory for the diagnosis of this rare condition. Afetab et al., described 19 cases of nipple adenoma over a period of 14 years; all patients were females with age ranging from 23 to 63 years. Most of the cases presented clinically with induration and ulceration. The diagnosis was clinically suspected in only 3 cases and the final diagnosis was confirmed by histology alone [12].

Similarly, our patient presented with bloody nipple discharge associated with extensive erosion raising the clinical suspicion of Paget's disease. Incisional biopsy was performed and histopathology report revealed a diagnosis, adenoma of nipple. Since complete excision is curative, local recurrence has been reported in $30 \%$ of incompletely excised lesions [13], our patient underwent complete excision of the eroded nipple and part of the areola together with part of the retro-areolar breast tissue to achieve adequate excision and minimize local recurrence. The final histopathologic diagnosis showed adequately excised nipple adenoma.

In conclusion we report a rare case of nipple adenoma mimicking Paget's disease of breast which is a diagnostic challenge. Nipple adenoma should be considered as a part of differential diagnosis when there is severe 
nipple erosion. Complete excision is the treatment of choice to avoid local reccurence.

\section{Acknowledgments}

We thank Dr. Abdul-Wahed Meshikhes, Consultant surgeon at Department of Surgery, King Fahad Specialist Hospital, Dammam 31444, Saudi Arabia, for revising the manuscript.

\section{References}

[1] Kijima, Y., Matsukita, S., Yoshinaka, H., Owaki, T. and Aikou, T. (2006) Adenoma of the Nipple: Report of a Case. Breast Cancer, 13, 95-99. http://dx.doi.org/10.2325/jbcs.13.95

[2] Carter, E. and Dyess, D.L. (2004) Infiltrating Syringomatous Adenoma of the Nipple: A Case Report and 20-Year Retrospective Review. The Breast Journal, 10, 443-447. http://dx.doi.org/10.1111/j.1075-122X.2004.21518.X

[3] Tavassoli, F.A. and Devillee, P. Editors (2003) World Health Organisation Classification of Tumours: Pathology and Genetics of Tumours of the Breast and Female Genital Organs. IARC Press, Lyon.

[4] Healy, C.E., Dijikstra, B., Walsh, M., Hill, A.D. and Murphy, J. (2003) Nipple Adenoma: A Differential Diagnosis for Paget’s Disease. The Breast Journal, 9, 325-326. http://dx.doi.org/10.1046/j.1524-4741.2003.09417.x

[5] Sato. T., Muto, I., Hasegawa, M., Aono, T., Okada, T., Tamura, T., et al. (2007) A Rare Case of Invasive Ductal Carcinoma with Hyperprolactinemia. Breast Cancer, 14, 302-306. http://dx.doi.org/10.2325/jbcs.14.302

[6] Jones, M.W. and Tavassoli, F.A. (1995) Co-Existance of Nipple Duct Adenoma and Breast Carcinoma: A Clinicopathologic Study of 5 Cases and Review of Literature. Modern Pathology, 8, 633-636. http://dx.doi.org/10.1097/00000478-198307080-00003

[7] Rosen, P.P. (1983) Syringomatous Adenoma of the Nipple. The American Journal of Surgical Pathology, 7, 739-745.

[8] Rosen, P.P. (2009) Rosen’s Breast Pathology. 3rd Edition, Lippincott William \& Wilkins, Philadelphia.

[9] Da Costa, D., Taddese, A., Cure, M.L., Gerson, G., Poppiti Jr., R. and Esserman, L. (2007) Common and Unusual Diseases of the Nipple-Areolar Complex. Radiographics, 27, S65-S77. http://dx.doi.org/10.1148/rg.27si075512

[10] Montemarano, A.D., Sau, P. and James, W.D. (1995) Superficial Papillary Adenomatosis of the Nipple: A Case Report and Review of the Literature. Journal of the American Academy of Dermatology, 33, 871-875. http://dx.doi.org/10.1016/0190-9622(95)90425-5

[11] Tavassoli, F.A. (1999) Pathology of the Breast. 2nd Edition, Appleton \& Lange, Stamford.

[12] Afetab, K., Indrees, R., Rauf, F. and Kayani, N. (2010) Nipple Adenoma of Breast: A Masquerader of Malignancy. Journal of the College of Physicians and Surgeons Pakistan, 20, 472-474.

[13] Chang, C.K., Jacobs, I.A., Calilao, G. and Salti, G.I. (2003) Metastatic Infiltrating Syringomatous Adenoma of the Breast. Archives of Pathology Laboratory Medicine, 127, E155-E156. 
Scientific Research Publishing (SCIRP) is one of the largest Open Access journal publishers. It is currently publishing more than 200 open access, online, peer-reviewed journals covering a wide range of academic disciplines. SCIRP serves the worldwide academic communities and contributes to the progress and application of science with its publication.

Other selected journals from SCIRP are listed as below. Submit your manuscript to us via either submit@scirp.org or Online Submission Portal.
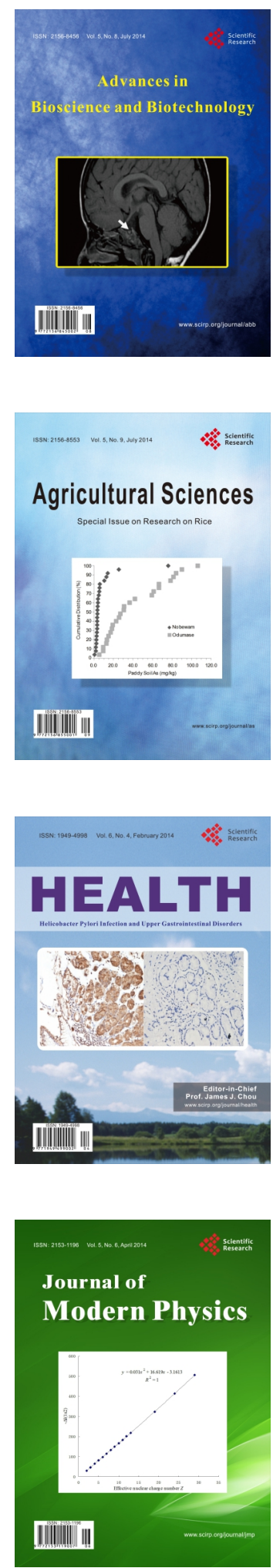
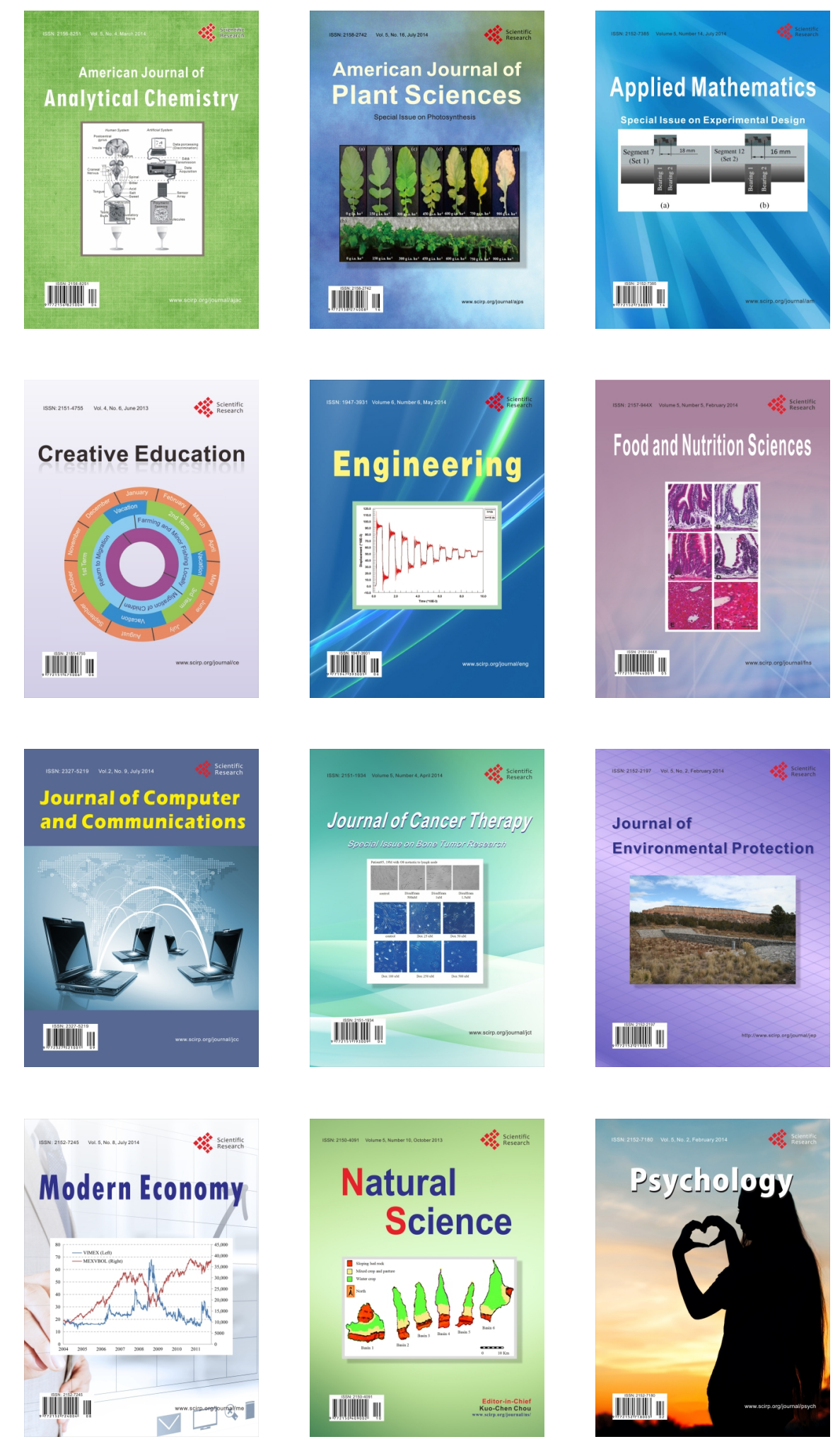